\title{
CHANGES IN THE FINANCIAL RESULTS OF CORPORATIONS IN CITIES IN EASTERN EUROPE
}

DOI: https://doi.org/10.18509/AGB.2019.02

UDC: 334.72:658.14/.17(4-11)"2008/2015"

\section{Piotr Raźniak, Sławomir Dorocki, Anna Winiarczyk-Raźniak, Monika Plaziak, Anna Irena Szymańska}

\author{
Institute of Geography, Pedagogical University of Krakow, Poland
}

corresponding author: piotr.razniak@up.krakow.pl

submitted: 21.02 .2018

accepted: 23.05.2018

published: 01.11.2018

\begin{abstract}
Major corporations represent an important aspect of economic life that affects the rank of a city on the international stage. The purpose of the study is to determine the financial results and sectoral differentiation of cities home to the largest corporate headquarters in the region often described as Eastern Europe. This determination was made based on revenue and net profits generated by 500 major corporations with their headquarters in Eastern Europe in the years 2008 and 2015. Research has shown that revenue and net profit of key corporations in the region slightly increased despite the downturn triggered by the global financial crisis in 2008 and 2009. The largest number of firms and also the best financial results were noted in Prague, Warsaw, and Budapest. At the same time, the close proximity of the original 15 EU states yields a positive impact on corporate presence - the number of corporations increases with decreasing distance to the former EU boundary. History also plays an important role in the presence of major corporations in Eastern Europe. The largest number of corporations are found in countries that were independent prior to 1990. The next largest group of countries in this study consists of states formerly part of the Soviet Union. Finally, the smallest number of large corporations are found in countries formerly part of Yugoslavia.
\end{abstract}

Key words: headquarters, central europe, cities, corporate finance

\section{INTRODUCTION}

Cities in Central and Eastern Europe experiencing political and economic change since 1989 are examined in the context of their transition from socialism to capitalism in effect since the early 1990s. However, the development of cities in this region is largely also determined by other processes such as physical modernization, non-political shifts, and globalization [1], [2]. In the early 1990s the economies of countries in this part of Europe experienced collapse mainly due to the political collapse of their main trading partner - the Soviet Union. Until 1991 fifteen republics of the Soviet Union were closely integrated via a centralized Soviet economic model with other countries in Central and Eastern Europe. Following political and economic collapse in Russia in the early 1990s, other countries in Central and Eastern Europe experienced faster economic bounce than did former Soviet republics [3]. Many former stateowned companies, especially those in the heavy industrial sector, went bankrupt, being replaced by dynamically growing private companies partly financed by foreign capital. The period experienced a mass-scale privatization of state-owned enterprises, with the new shareholders being large corporations headquartered outside of Central and Eastern Europe [4]

A free market economy was introduced in Central and Eastern Europe, which led to the acceleration of globalization processes in the region. Both globalization and the integration of the region with the European Union produced a significant impact on the growth of cities in terms of their spatial structure, main functions, and spatial processes and corresponding processes in their peripheral areas [5]. Many post-socialist countries in the region have also experienced suburbanization since the early 1990s. All countries in Central and Eastern Europe have experienced the migration of big city residents to suburban areas on a larger scale than before 1989 . This process further accelerated in the last decade or so making urban decentralization a key feature of urban growth in the region [6], [7]. It is the view of many researchers that suburbanization represents one of the main processes impacting post-socialist 
cities in Central and Eastern Europe in the 21st century [8], [9], [10], [11].

The most important companies operating in the region during the socialist period were located within city limits - most often close to city centers. The first main signs of industrial and service deconcentration occurred in the 1990s [12], [13]. Only a few world-leading companies are headquartered presently in this part of Europe [14],

\section{DATA}

The study presents the economic potential of cities in Central and Europe via the financial performance of the largest companies tallied by the Deloitte Corporation in its Deloitte Central Europe Top 500 Report for the years 2008, 2012, and 2015. The Deloitte report has been published every year since 2008 and covers the largest 500 corporations with a headquarters in Central Europe - the report is based on corporate revenue. The main list does not include the banking and insurance sectors, which are examined by Deloitte in a separate publication. An examination of the largest corporations in cities implies that the two sectors cannot be excluded. Hence, 50 companies from each of the two sectors

\section{METHODS}

The index of innovativeness for cities discussed in this study is based on another index known as the potential of international position (PIP) index, which is in turn based on the standardized deviation of sales revenue (RS) and net income (IN). In addition, a city's potential also reflects the number of corporate headquarters located in each city [20].

$$
P I P=\frac{z_{R S}+z_{N I}}{2}
$$

where

$$
\begin{aligned}
& z_{R S}=\frac{z_{R S} * 100}{\max \left(z_{R S}\right)} \\
& z_{N I}=\frac{z_{N I} * 100}{\max \left(z_{N I}\right)}
\end{aligned}
$$

\section{CORPORATE HEADQUARTERS \\ IN CENTRAL AND EASTERN EUROPE}

Since 2008 the largest number of headquarters of the largest companies in Central Europe has been found in Warsaw. However, the number of corporate headquarters in Warsaw declined from 110 in 2008 to 97 in 2015. Prague was the next largest corporate headquarters city in the region with $60 \mathrm{HQs}$ in 2015. Budapest was third in line with 51 . The next top spots belonged to Bucharest,
[15]. These companies are often described as world command and control centers [16]. Companies of this type are discussed for Central and Eastern Europe in [17].

The purpose of the paper is to discuss financial performance results for the largest global corporations by city, country, and groups of countries headquartered in the region of Central and Eastern Europe.

were added to the top 500 list creating a top 600 list of the largest corporations in the region of Central Europe [18]. The Deloitte top list report covers the following countries: Albania, Bosnia and Hercegovina, Bulgaria, Croatia, Czech Republic, Estonia, Hungary, Kosovo, Latvia, Lithuania, Macedonia, Moldova, Poland, Romania, Serbia, Slovakia, Slovenia, Ukraine. Russia and Belarus are not included due to problems in obtaining data from these two countries and certain problems with the credibility of the data that are [19]. In the present study, corporation data for cities were aggregated for each studied metropolitan area in Central and Eastern Europe.

value normalized using SD sales revenue (max value $=100$ )

value normalized using SD net income (max value $=100$ )

Maximum PIP index value can be 100 .

The studied countries may be placed in three distinct groups based on their history [18]:

- Group 1: best developed countries; independent prior to 1990 (Poland, Slovakia and Czech Republic of former Czechoslovakia, Hungary, Bulgaria, Romania)

- Group 2: countries part of the Soviet Union prior to 1990 (Lithuania, Latvia, Estonia, Ukraine)

- Group 3: countries part of Yugoslavia prior to its dissolution (Slovenia, Bosnia and Herzegovina, Croatia, Montenegro, Kosovo, Macedonia, Serbia)

Bratislava, Kiev, and Ljubljana. The overall pattern is that of capital cities winning the top spots in terms of the number of corporate headquarters. The largest number of headquarters are found in Poland - and the first 20 cities in the ranking. In addition to Warsaw, Poland boasts seven other cities in the top 20. The predominant pattern is reversed in Ukraine, with 56 headquarters in 2008 and 54 in 2012 and 
only 32 in 2015 . Kiev lost the largest number of corporate headquarters in the period $2012-2015$. The same was true of Ukrainian cities located to the east of Kiev. This is most likely true due to the armed conflict between Russian and Ukraine in eastern Ukraine and Russia's annexation of the Crimean peninsula in southern Ukraine (Fig. 1).

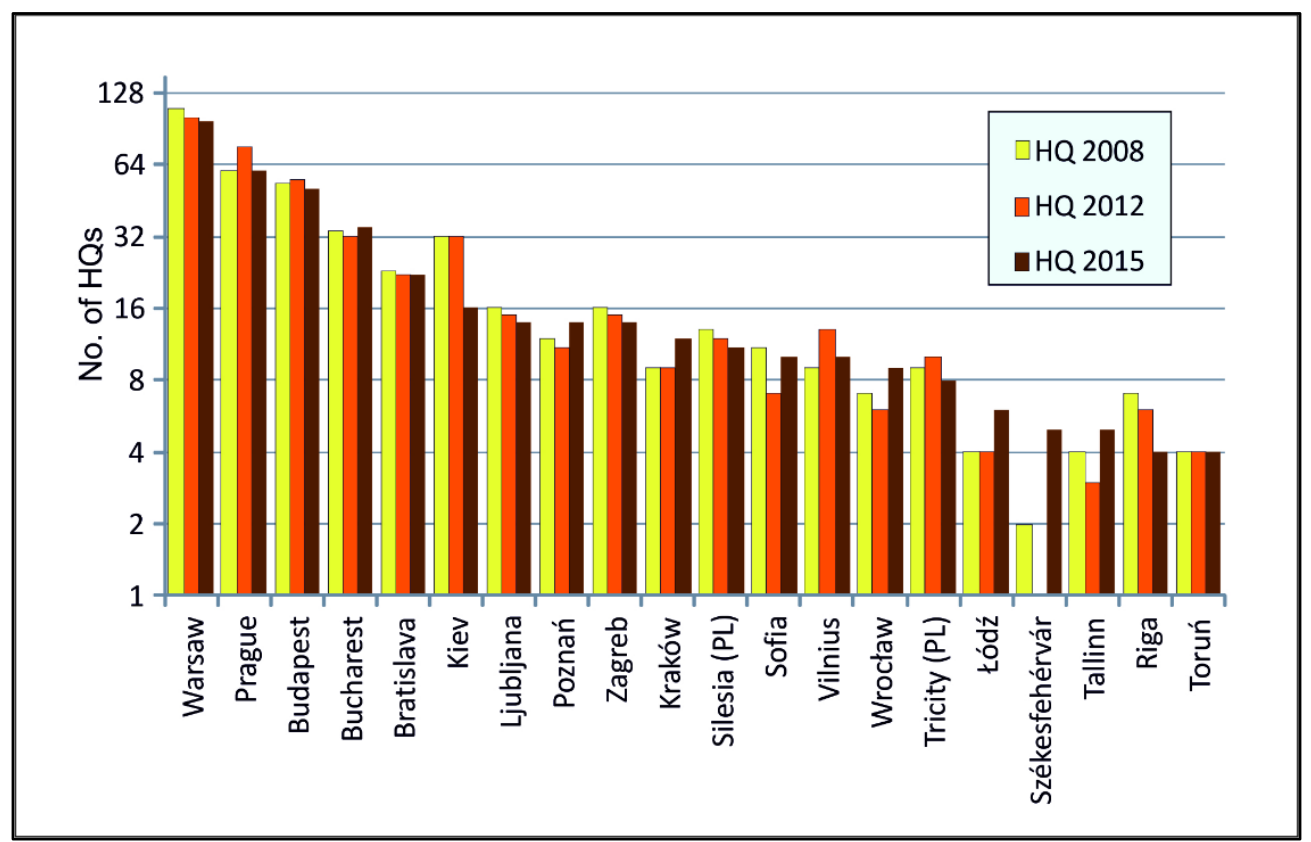

Figure 1. Number of corporate headquarters in cities in Central and Eastern Europe in the period $2008-2015$ (top 20 cities).

source: Author's own work based on Deloitte Central Europe Top 500 Reports

However, the number of corporate headquarters does not correlate with a city's potential of international position (PIP). Yet, in the case of the most important cities in the studied region, it is possible to observe a similar pattern between both sets of values. The highest PIP value of 100 was noted for Warsaw in 2008 and again in 2015. Prague was ranked second during the study period having surpassed Warsaw in 2012 despite a smaller number of corporate headquarters.

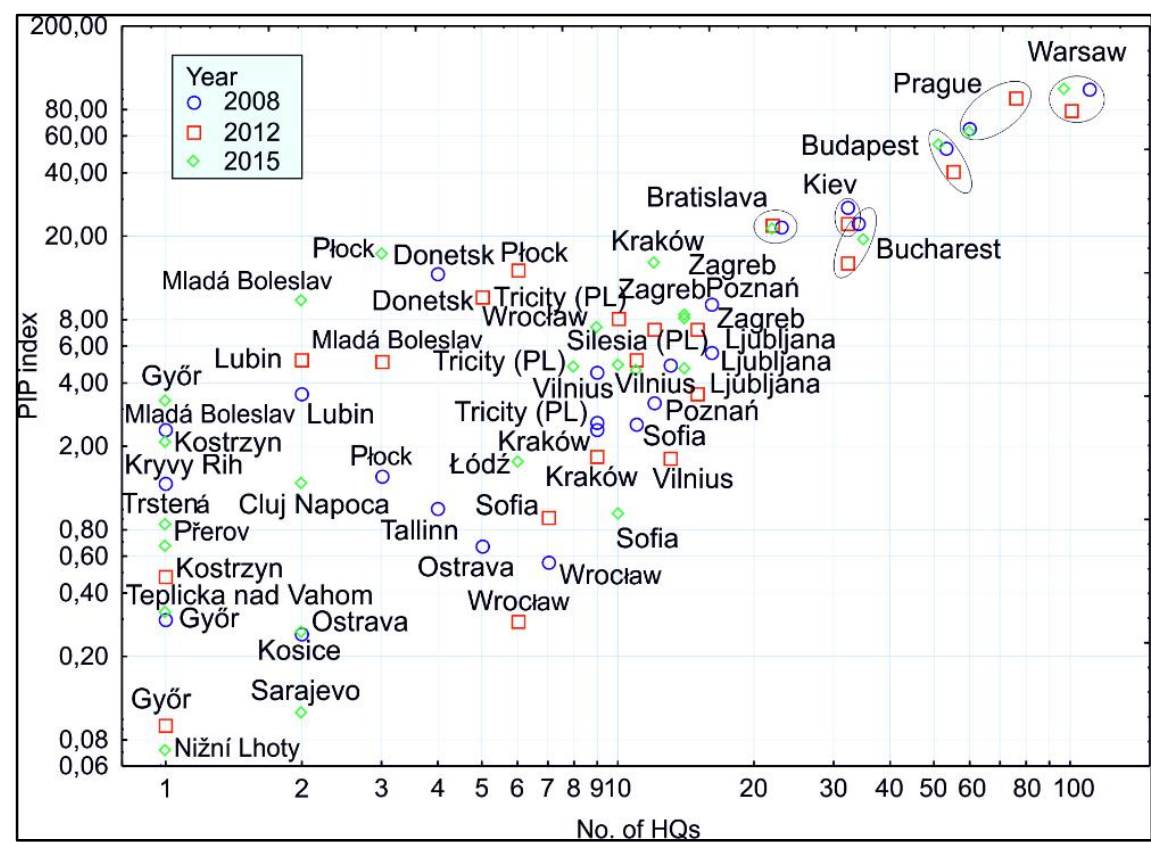

Figure 2. Potential international position index values (PIP) for the period $2008-2015$ source: Author's own work based on Deloitte Central Europe Top 500 Reports

The largest increases in PIP values during the period $2008-2015$ were noted for the following
Polish cities: Płock $(+15.0)$, Kraków $(+12.6)$, Wrocław (+6.9), Poznań $(+5.3)$. A large change in 
PIP was also noted for the Czech city of Mlada Boleslav (+7.6). The largest decline in PIP value was noted for two Ukrainian cities - Kiev (-38.0) and Donetsk (-20.3). The third largest decline was noted for the Polish city of Lubin (-8.4) (Fig. 2). The number of corporate headquarters was the largest in Poland for each of the studied years. The number of HQs in Poland declined slightly to 197 in 2012, but then increased to 213 in 2015. Poland held $35.5 \%$ of all top-ranked HQs in Central Europe in 2015. The Czech Republic was ranked second in 2015 with 93 HQs; however, Hungary was ranked second in terms of PIP. The number of corporate headquarters declined only in Poland and Bulgaria in Group 1 in the period $2008-2015$. However, the group as a whole gained HQs rising from 466 to 492 $(+5.6 \%)$. On the other hand, PIP values rose markedly for Poland, Hungary, and Bulgaria. Of the group 1 countries, Poland is the leader as manifested by the fact that $82 \%$ of the examined corporations have established a presence in Poland for the group 1. The number of HQs in Group 2 is much smaller, and it declined from 79 in 2012 to 55 in 2015 .

Table 1. Number of headquarters and index values by country and group of countries

\begin{tabular}{|l|r|r|r|r|r|r|}
\hline & \multicolumn{2}{|c|}{ No of Headquarters } & \multicolumn{2}{|c|}{ PIP index summary } \\
\cline { 2 - 7 } Country/Region & $\mathbf{2 0 0 8}$ & $\mathbf{2 0 1 2}$ & $\mathbf{2 0 1 5}$ & $\mathbf{2 0 0 8}$ & $\mathbf{2 0 1 2}$ & $\mathbf{2 0 1 5}$ \\
\hline Bulgaria & 15 & 9 & 12 & $-12,70$ & $-4,27$ & $-3,23$ \\
\hline Czech Republic & 85 & 107 & 93 & 29,81 & 57,41 & 20,81 \\
\hline Hungary & 73 & 75 & 78 & 2,40 & $-14,38$ & 21,30 \\
\hline Poland & 218 & 197 & 213 & 1,72 & 21,17 & 57,25 \\
\hline Romania & 44 & 46 & 57 & $-6,85$ & $-22,15$ & $-16,81$ \\
\hline Slovakia & 31 & 35 & 39 & 7,36 & $-1,90$ & $-4,53$ \\
\hline GROUP 1 total & $\mathbf{4 6 6}$ & $\mathbf{4 6 9}$ & $\mathbf{4 9 2}$ & $\mathbf{2 1 , 7 5}$ & $\mathbf{3 5 , 8 8}$ & $\mathbf{7 4 , 7 9}$ \\
\hline Estonia & 4 & 3 & 5 & 1,01 & $-1,40$ & $-0,23$ \\
\hline Latvia & 7 & 6 & 4 & $-1,98$ & $-0,01$ & $-0,51$ \\
\hline Lithuania & 13 & 16 & 14 & $-3,78$ & $-5,44$ & 0,10 \\
\hline Ukraine & 57 & 54 & 32 & 12,38 & 5,32 & $-48,68$ \\
\hline GROUP 2 total & $\mathbf{8 1}$ & $\mathbf{7 9}$ & $\mathbf{5 5}$ & $\mathbf{7 , 6 2}$ & $\mathbf{- 1 , 5 3}$ & $\mathbf{- 4 9 , 3 3}$ \\
\hline Bosnia and Herzegovina & 0 & 2 & 2 & & $-6,73$ & 0,11 \\
\hline Croatia & 18 & 17 & 19 & 3,02 & 1,80 & $-3,52$ \\
\hline Rep. of Macedonia & 1 & 1 & 1 & $-3,53$ & $-3,96$ & $-2,12$ \\
\hline Serbia & 8 & 7 & 7 & $-11,91$ & $-8,85$ & $-8,79$ \\
\hline Slovenia & 26 & 25 & 24 & $-16,96$ & $-16,60$ & $-11,15$ \\
\hline GROUP 3 total & $\mathbf{5 3}$ & $\mathbf{5 2}$ & $\mathbf{5 3}$ & $\mathbf{- 2 9 , 3 7}$ & $\mathbf{- 3 4 , 3 5}$ & $\mathbf{- 2 5 , 4 6}$ \\
\hline
\end{tabular}

The number of corporate headquarters was the largest in Poland for each of the studied years. The number of HQs in Poland declined slightly to 197 in 2012, but then increased to 213 in 2015. Poland held $35.5 \%$ of all top-ranked HQs in Central Europe in 2015. The Czech Republic was ranked second in 2015 with 93 HQs; however, Hungary was ranked second in terms of PIP. The number of corporate headquarters declined only in Poland and Bulgaria in Group 1 in the period 2008 - 2015. However, the group as a whole gained HQs rising from 466 to 492 $(+5.6 \%)$. On the other hand, PIP values rose markedly for Poland, Hungary, and Bulgaria. Of the group 1 countries, Poland is the leader as manifested by the fact that $82 \%$ of the examined corporations have established a presence in Poland for the group 1. The number of HQs in Group 2 is much smaller, and it declined from 79 in 2012 to 55 in 2015 .

The cause of this is primarily related to the armed conflict between Russia and Ukraine. PIP values increased only in the case of Lithuania. In other Group 2 countries, a small increase in the number of corporate headquarters was noted. However, a decrease in the financial performance of Ukrainian companies triggered an overall decrease from 81 in 2008 to 55 in $2015(-32.1 \%)$. Group 3 appears quite stable compared with Group 2. The number of corporate headquarters in Group 3 in 2018 and 2015 was 53, while in 2012 the number was 52 . A decline occurred in the strongest country in Group 3 Slovenia. Serbia also lost one top-ranked corporation during this time period. On the other hand, Bosnia and Herzegovina did not feature a single corporation on the Deloitte list in 2008, but did feature two corporations in 2012 and 2015 (Tab. 1). Aside from Croatia, small increases in PIP values may be observed, although the values themselves are very small, with the highest PIP value in 2015 being 0.11 (Bosnia and Herzegovina). In short, Poland remains the home of the largest number of top-ranked companies in Central and Eastern Europe, while the largest decline has occurred in Ukraine, which is why Group 2 declined in general during the study period. With no changes in Group 3, it may be asserted that the place 
of Ukrainian companies may have been filled with the companies headquartered in countries classified as Group 1 (Tab. 1).

\section{RESULTS:}

There is a significant number of large companies in Central Europe; however, few of them play an important role in the world economy. Some Central European companies are simply regional affiliates of corporations headquartered outside of the studied region. However, there are also major companies in Central Europe that are headquartered in the region. The largest number of corporate headquarters are found in Warsaw, which despite a decline in their number has remained a leader in this field in Central Europe surpassing Prague and Budapest. Research has shown that the number of corporate headquarters does not necessarily correlate with the potential international position index - the largest increase in which was noted for Polish and Czech cities. On the other hand, Ukrainian cities suffered the largest declines.

One third of the examined top-ranked corporations are headquartered in Poland, although this number has experienced a small decline. On the other hand, the next two countries in line, the Czech Republic and Hungary, experienced an increase in the number of corporate headquarters during the study period. By far the "strongest" countries in the study were those that existed as independent states after World War II (Group 1). On the other hand, Group 2 (former USSR republics) and Group 3 (former Yugoslavia) countries had a similar number of topranked corporate headquarters during the study period. Yet, in terms of PIP index values, Group 3 surpassed Group 2 in 2015. The main cause of this is the armed conflict between Russia and Ukraine. This is why many companies located in Ukraine have lost their spot on the Deloitte list of top companies in Central Europe.

The case of Ukraine shows that an armed conflict regardless of its actual size - may strongly impact the financial performance of the largest companies headquartered in a conflict-ridden country. This is true even when the company headquarters is not located in the conflict zone itself - as seen in the case of the Ukrainian capital city of Kiev.

\section{REFERENCES:}

[1] Śleszyński, P. Economic control functions in Poland. Geographia Polonica, vol 88(4), pp 701-708, 2015. http://dx.doi.org/10.7163/GPol.0041.

[2] Śleszyński, P. Gospodarcze funkcje kontrolne w przestrzeni Polski. Warszawa: IGiPZ PAN, 2007.

[3] Tanning, L. \& Tanning, T. How Former Post-socialist Countries Have been the Economic Crisis? Transactions on Economic Crisis vol. 1(3), pp 2372-3254, 2014. DOI:10.15764/ER.2014.03002

[4] Froot, K.A. Foreign Direct Investment in Eastern Europe: Some Economic Considerations. [IN:] O. Blanchard, K. Froot, J. Sachs, (eds.), Transition in Eastern Europe, vol 2, pp 293-318, 1994. Chicago: University of Chicago Press.

[5] Hamilton, F. E. I., \& Dimitrovska-Andrews, K. \& Pichler-Milanović, N. (eds). Transformation of cities in central and Eastern Europe: Towards globalization, 2005. Tokyo - New York - Paris: United Nations University Press.

[6] Stanilov, K. \& Sýkora L. (eds.). Confronting Suburbanization: Urban Decentralization in Postsocialist Central and Eastern Europe, 2014. Wiley \& Sons, DOI: 10.1002/978111829586

[7] Raźniak, P. \& Winiarczyk-Raźniak, A. Influence of the societal security level on population migrations in Poland. Procedia - Social and Behavioral Sciences, vol 120, pp 2-12, 2014. DOI: 10.1016/j.sbspro.2014.02.075

[8] Kurek, S. \& Wójtowicz, M. \& Gałka, J. Does Commuting in Post-Socialist Second-Tier City Show Signs of Postsuburban Development? Evidence From Cracow. Mitteilungen der Österreichischen Geographischen Gesellschaft, vol 159, pp. 23-53, 2017.

[9] Brade, I. \& Herfert, G. \& Wiest, K. Recent trends and future prospects of sociospatial diff erentiation in urban regions of Central and Eastern Europe: A lull before the storm? Cities vol 26(5), pp 233-244, 2009.

[10] Kovács, Z. Social and economic transformation of historical neighbourhoods in Budapest. "Tijdschrift voor Economische en Sociale Geografie”, vol 100(4), pp 399-416, 2009. DOI: 10.1111/j.1467-9663.2009.00549.x

[11] Leetmaa, K. \& Tammaru, T. Suburbanization in countries in Transition: Destinations of suburbanizes in the Tallinn Metropolitan Area. Geografiska Annaler series B, vol 89(2), 2007. DOI: https://doi.org/10.1111/j.14680467.2007.00244.x

[12] Kurek S. \& Rachwał T. \& Wójtowicz M. Industrial and commercial suburbanization in post-socialist.city: the Kraków Metropolitan Area (Poland). Annales Universitatis Paedagogicae Cracoviensis, Studia Geographica, vol 5, pp 55-76, 2014. 
[13] Płaziak, M. \& Szymańska, A.I. Construction Sector in the Czech Republic and Poland: Focus on the Housing Segment in Selected Regions, Entrepreneurial Business and Economics Review. [IN]: R. Rybkowski, K. Wach (eds.). Globalisation of Economies and Industries, vol 2(2), pp 47-64, 2014.

[14] Raźniak, P. \& Winiarczyk-Raźniak, A. Did the 2008 global economic crisis affect large firms in Europe? Acta Geographica Slovenica,vol 55(1), pp 127-139, 2015. DOI: http://dx.doi.org/10.3986/AGS.740

[15] Raźniak, P. \& Dorocki, S. \& Winiarczyk-Raźniak, A. Permanence of Economic Potential of Cities Based on Sector Development. Chinese Geographical Sciences, vol 1(27), pp 123-136, 2017. DOI: 10.1007/s11769-017-0850-5.

[16] Taylor, P.J. \& Csomós, G. Cities as control and command centres: Analysis and interpretation. Cities, vol 29(6), pp 408-411, 2012. DOI: https://doi.org/10.1016/j.cities.2011.09.005

[17] Raźniak, P. \& Dorocki, S. \& Winiarczyk-Raźniak, A. Eastern European cities as command and control centres in time of economic crisis. Acta Geographica Slovenica, vol 58(2), pp 101-110, 2018. DOI: http://dx.doi.org/10.3986/AGS.3124

[18] Raźniak, P. \& Dorocki, S. \& Winiarczyk-Raźniak, A. \& Płaziak, M. \& Szymańska, A.I. Zmiany pozycji ekonomicznej miast Europy Środkowo-Wschodniej w przypadku kryzysu dominującego sektora. Ekonomista, vol2017(1), pp 67-83, 2017.

[19] Deloitte, www.deloitte.com, access 2017-11-03

[20] Raźniak, P. Zróżnicowanie kondycji finansowej korporacji w Europie Wschodniej w czasie spowolnienia gospodarczego. Państwo i Społeczeństwo, vol 17(2), pp 57-70, 2017. 